Zeszyty Naukowe Szkoły Głównej Gospodarstwa Wiejskiego w Warszawie

Problemy Rolnictwa Światowego tom 18 (XXXIII), zeszyt 2, 2018: 70-81

DOI: $10.22630 /$ PRS.2018.18.2.35

Antoni Faber', Zuzanna Jarosz ${ }^{2}$

Instytut Uprawy Nawożenia i Gleboznawstwa - Państwowy Instytut Badawczy

w Puławach

\title{
Modelowanie emisji podtlenku azotu i amoniaku w skali regionalnej oraz w Polsce
}

\section{Modeling of Emission of Nitrous Oxide and Ammonia on a Regional Scale and in Poland}

Synopsis. Celem badań była weryfikacja przyjętych w krajowych inwentaryzacjach emisji gazów cieplarnianych współczynników emisji bezpośredniej $\mathrm{N}_{2} \mathrm{O}$ i $\mathrm{NH}_{3}$ oraz oszacowanie emisji bezpośredniej i pośredniej $\mathrm{N}_{2} \mathrm{O}$ w systemach uprawy zwiększających sekwestrację węgla. Symulacje wykonywano przy użyciu modelu DNDC dla województw i Polski z użyciem dwudziestoletnich serii danych meteorologicznych. Stwierdzono, że symulowana emisja bezpośrednia podtlenku azotu dla Polski była zgodna z przyjętym współczynnikiem emisji. Symulowana emisja amoniaku była większa od przyjętego współczynnika emisji. Zastosowanie w symulacjach systemów uprawy zwiększających sekwestrację węgla organicznego, takich jak uprawa konserwująca oraz nawożenie obornikiem, zwiększało: wymycie i spływ powierzchniowy azotu oraz emisję bezpośrednią i pośrednią $\mathrm{N}_{2} \mathrm{O}$. Wzrost tych emisji powinien być skompensowany z naddatkiem przyrostem ilości sekwestrowanego węgla organicznego w glebie, jeśli bilans emisji gazów cieplarnianych ma być ujemny.

Slowa kluczowe: azot, bilans, emisja, podtlenek azotu, amoniak

\begin{abstract}
The aim of the research was to verify the $\mathrm{N}_{2} \mathrm{O}$ direct and $\mathrm{NH}_{3}$ emission factors adopted in national inventories, and to estimate the direct and indirect $\mathrm{N}_{2} \mathrm{O}$ emissions in cultivation systems increasing carbon sequestration. Simulations were performed using the DNDC model for NUTS2 and Poland with the use of twenty-year series of meteorological data. It was found that the simulated direct emission of nitrous oxide for Poland was in line with the adopted emission factor. The simulated ammonia emission was greater than the assumed emission factor. Use in simulations of cultivation systems increasing the sequestration of organic carbon, such as conservation system and conventional system with manure fertilization, increased: surface leaching and runoff of nitrogen as well as direct and indirect $\mathrm{N}_{2} \mathrm{O}$ emission. The increase of these emissions must be compensated with an allowance increase in the amount of sequestered organic carbon in the soil if the greenhouse gas emissions balance is to be negative.
\end{abstract}

Key words: nitrogen, balance, emission, nitrous oxide, ammonia

JEL Classification: Q15, Q54

\footnotetext{
${ }^{1}$ prof. dr hab., IUNG-PIB, ul. Czartoryskich 8, 24-100 Puławy, e-mail: faber@iung.pulawy.pl; https://orcid.org/0000-0002-3055-1968

${ }^{2}$ dr, IUNG-PIB, ul. Czartoryskich 8, 24-100 Puławy, e-mail: zjarosz@iung.pulawy.pl; https://orcid.org/0000-0002-3428-5804
} 


\section{Wprowadzenie}

Zachodzące zmiany klimatu mają charakter globalny i powodowane są przez czynniki naturalne oraz antropogeniczne. Według obecnego stanu wiedzy ocieplenie klimatu w ostatnich 50 latach należy przypisać głównie działalności człowieka związanej ze zwiększaniem emisji gazów cieplarnianych (IPCC, 2013). Dlatego globalne, wielostronne umowy międzynarodowe dążą do ograniczenia emisji gazów cieplarnianych takich jak: dwutlenek węgla $\left(\mathrm{CO}_{2}\right)$, metan $\left(\mathrm{CH}_{4}\right)$, podtlenek azotu $\left(\mathrm{N}_{2} \mathrm{O}\right)$, sześciofluorek siarki $\left(\mathrm{SF}_{6}\right)$, fluorowęglowodory (HFCs) oraz perfluorowęglowce (PFCs) (UNFCCC, 1992; Dziennik Ustaw, 2005; Dziennik Urzędowy UE, 2016).

Rolnictwo, jako sektor non-ETS do roku 2020 nie miało wyznaczonych celów redukcji emisji gazów cieplarnianych, a jedynie zobowiązane było do raportowania wielkości powodowanych emisji $\mathrm{CH}_{4}$ i $\mathrm{N}_{2} \mathrm{O}$. W uzgadnianej na lata 2021-2030 polityce klimatycznej UE sektory nie objęte handlem emisjami, w tym rolnictwo, mają ograniczyć emisję gazów cieplarnianych w UE o 30\% w stosunku do 2005 r. (EC, 2016a). Wstępnie uzgodniono, że Polska powinna w tych sektorach ograniczyć emisję o 7\% w stosunku do 2005 r. (EC, 2016a). Według propozycji emisje $\left(\mathrm{CH}_{4}, \mathrm{~N}_{2} \mathrm{O}\right)$ oraz pochłanianie gazów cieplarnianych $\left(\mathrm{CO}_{2}\right)$ z użytkowania gruntów, zmian użytkowania gruntów oraz leśnictwa (LULUCEF) zostaną włączone do ramowej polityki klimatycznej UE do 2030 r. (EC, 2016b). Nakładać to będzie na kraje członkowskie obowiązek wykazywania, że emisje powodowane $\mathrm{w}$ LULUCEF są kompensowane przez pochłanianie gazów cieplarnianych. Nie będzie to jednak obligować rolników do ograniczania emisji, a jedynie stanowić ma zachętę do stosowania praktyk rolniczych przyjaznych klimatowi. W praktyce przyszłe działania $\mathrm{w}$ LULUCEF mają więc prowadzić do zwiększenia pochłaniania $\mathrm{CO}_{2}$ przez zwiększenie sekwestracji węgla organicznego w glebach lub poprzez ograniczenie emisji GHG (United Nations..., 2018).

W krajowych inwentaryzacjach emisji gazów cieplarnianych i pochłaniania $\mathrm{CO}_{2}$ wykorzystuje się metodyki szacunków emisji opracowane przez IPCC (IPCC, 2006a). Polegają one na stosowaniu w szacunkach empirycznych współczynników emisji przyjętych jako uniwersalne (poziom 1) lub dostosowane do warunków danego kraju (poziom 2). Na przykład wielkość bezpośredniej emisji $\mathrm{N}_{2} \mathrm{O}$ z użytkowanych rolniczo gleb szacuje się mnożąc dawkę zastosowanego w nawożeniu azotu przez współczynnik emisji $1 \%$ (poziom 1) i otrzymuje się emisję $\mathrm{N}_{2} \mathrm{O}-\mathrm{N}$. Współczynnik ten jest więc mocno zgeneralizowany, wiadomo bowiem, że w różnych warunkach może mieć on wartości leżące w przedziale 0,3-3,0\%. Pewną poprawę dokładności szacunków może zapewnić dostosowanie współczynnika do warunków danego kraju (poziom 2) lub zastosowanie modeli (poziom 3), które, jak się przyjmuje, mogą dawać szacunki dokładniejsze (IPCC, 2006a, 2006b, 2006c).

\section{Dane i metody}

W badaniach wykorzystano model DNDC (wersja 9.2) (Giltrap i in., 2010) w kalibracji opracowanej w JRC EC dla Europy (Leip, 2007; Leip, 2008). Model ten ma bogate referencje i wykorzystywany był z powodzeniem w wielu miejscach na świecie do symulacji bilansów węgla, azotu i wody, emisji $\mathrm{CH}_{4}$ i $\mathrm{N}_{2} \mathrm{O}$ oraz sekwestracji węgla 
organicznego w glebach pod uprawami rolniczymi (poziom pola). Przed zastosowaniem model był rekalibrowany w IUNG-PIB.

Symulacje wykonywano dla kategorii agronomicznych gleb ciężkich, średnich, lekkich oraz bardzo lekkich. Dla tych gleb ustalono metodą ekspercka, na podstawie struktury zasiewów, prawdopodobne zmianowania roślin w 16 województwach. Dawki azotu (N) pod każdą roślinę zmianowania oraz kategorię gleb ustalono dla plonów potencjalnie osiaganych przy małym zapotrzebowaniu na $\mathrm{N}$ i stosowano w dwóch dawkach dzielonych w postaci saletry amonowej (Jadczyszyn i in., 2003). Symulacje wykonywano dla okresu dwudziestolecia $\mathrm{z}$ wykorzystaniem średnich dobowych danych meteorologicznych (temperatura minimalna, maksymalna, opad) udostępnionych przez JRC EC. Dane meteorologiczne były specyficzne dla każdego województwa. Symulacjami objęto trzy systemy uprawy: a) płużnej z mineralnym nawożeniem $\mathrm{N}$ i zbiorem resztek pożniwnych, który był traktowany jako referencyjny dla dwóch kolejnych systemów zwiększających sekwestrację węgla, b) uproszonej $\mathrm{z}$ mineralnym nawożeniem $\mathrm{N}$ oraz pozostawieniem resztek pożniwnych na polu oraz c) płużnej z mineralnym nawożeniem $\mathrm{N} \mathrm{i}$ obornikiem (170 kg N ha ${ }^{-1}$ raz w zmianowaniu roślin; stała wartość we wszystkich symulacjach) i zbiorem resztek pożniwnych. Badane systemy uprawy imitują: a) uprawę w gospodarstwach bezinwentarzowych zbierających resztki pożniwne b) uprawę w gospodarstwach bezinwentarzowych stosujących uprawę konserwującą z pozostawieniem na polu całej ilości resztek pożniwnych oraz c) uprawę $\mathrm{w}$ tradycyjnych gospodarstwach posiadających inwentarz i stosujących obornik. Ogółem wykonano 3840 rocznych symulacji (20 lat x 4 kategorie gleb x 3 systemy uprawy x 16 województw). Symulowanymi charakterystykami były: dawka zastosowanego $\mathrm{N}$ w nawozach mineralnych i naturalnych $\left(\mathrm{kg} \mathrm{N} \mathrm{ha}^{-1} \mathrm{r}^{-1}\right)$, pobranie $\mathrm{N}$ wraz z plonem głównym i ubocznym $\left(\mathrm{kg} \mathrm{ha}^{-1} \mathrm{r}^{-1}\right)$, wymycie $\mathrm{N}$ z nawożonych gleb $\left(\mathrm{kg} \mathrm{N}^{-1} \mathrm{r}^{-1}\right)$, spływ powierzchniowy $\mathrm{N}(\mathrm{kg}$ $\left.\mathrm{ha}^{-1} \mathrm{r}^{-1}\right)$, emisja bezpośrednia $\mathrm{N}_{2} \mathrm{O}\left(\mathrm{kg} \mathrm{N}_{2} \mathrm{O}-\mathrm{N} \mathrm{ha}^{-1} \mathrm{r}^{-1}\right)$, emisja bezpośrednia $\mathrm{N}_{2} \mathrm{O}$ w stosunku do dawki (\%), emisja amoniaku ( $\mathrm{kg} \mathrm{NH}_{3}-\mathrm{N} \mathrm{ha}^{-1} \mathrm{r}^{-1}$ ), emisja amoniaku w stosunku do dawki (\%), emisja pośrednia $\mathrm{N}_{2} \mathrm{O}\left(\mathrm{kg} \mathrm{N}_{2} \mathrm{O}-\mathrm{N} \mathrm{ha}^{-1} \mathrm{r}^{-1}\right)$ oraz emisja bezpośrednia $\mathrm{i}$ pośrednia $\mathrm{N}_{2} \mathrm{O}\left(\mathrm{kg} \mathrm{N}_{2} \mathrm{O}-\mathrm{N} \mathrm{ha}^{-1} \mathrm{r}^{-1}\right)$.

Uzyskane z symulacji serie wyników, z dwudziestolecia dla kategorii gleb w województwach, zostały uśrednione do wartości średniorocznych (średnie arytmetyczne). Następnie dla systemów uprawy policzono średnie ważone charakterystyki symulowanych parametrów. Jako wagę przyjęto areały kategorii gleb w każdym województwie. Średnie ważone wartości parametrów w województwach miały rozkłady skośne. Z tego względu symulowane charakterystyki dla Polski przedstawiono jako mediany wartości uzyskanych w województwach, zaś rozrzut wyników wokół mediany jako medianowe odchylenie bezwzględne wyrażone w procentach od mediany. Dla każdego województwa i Polski policzono ponadto średnie ważone wartości analizowanych charakterystyk $\mathrm{z}$ systemów uprawy. Jako wagi przyjęto pożądane udziały systemów uprawy a) $10 \%$, b) $40 \%$ oraz c) $50 \%$.

Głównymi celami pracy była weryfikacja współczynników emisji $\mathrm{N}_{2} \mathrm{O}$ i $\mathrm{NH}_{3}$ oraz oszacowanie bezpośredniej $\mathrm{i}$ pośredniej emisji podtlenku azotu w systemach uprawy zwiększających sekwestrację węgla (b i c w stosunku do a). Dane na ten temat mają istotne znaczenie dla bilansów emisji gazów cieplarnianych, ponieważ $\mathrm{N}_{2} \mathrm{O}$ wywołuje 298 razy większy efekt cieplarniany niż $\mathrm{CO}_{2} . \mathrm{Z}$ tego względu dla praktyki rolniczej istotnym jest przed zastosowaniem systemów zwiększających sekwestrację węgla poznanie ich wpływu na emisję $\mathrm{N}_{2} \mathrm{O}$ oraz bilans emisji gazów cieplarnianych w systemach uprawy. 


\section{Wyniki badań}

Podstawowym warunkiem ograniczenia strat $\mathrm{N}$ w uprawach rolnych, wymywania, spływu powierzchniowego, emisji gazowych, jest dostosowanie dawek $\mathrm{N}$ do potrzeb nawozowych roślin. W przeprowadzonych eksperymentach symulacyjnych oszacowane dawki N były największe w systemie uprawy (b), co wynikało z dodatkowych ilości N wprowadzonych ze słomą oraz dodatku tego składnika w ilości $6 \mathrm{~kg}$ N na każdą tonę słomy wprowadzonej do gleby (tab. 1). Dodatek ten jest konieczny dla lepszego mikrobiologicznego rozkładu słomy bez ograniczenia pobierania $\mathrm{N}$ przez rośliny wskutek jego uwstecznienia przez mikroorganizmy rozkładające słomę. Mniejsze dawki N stwierdzono dla systemu uprawy z obornikiem (c), a najmniejsze w systemie uprawy (a) (tab. 1). Wysymulowana dawka $\mathrm{N}$ dla Polski w systemie (a), w którym stosowano wyłącznie azot w nawozach mineralnych, wynosiła $96 \mathrm{~kg} \mathrm{~N}^{-1} \mathrm{i}$ była mniejsza od dawki $\mathrm{N}$ stosowanej obecnie na gruntach ornych (105 kg N ha-1) według GUS (GUS, 2018a, b). Pamiętać jednak należy, że w Polsce około 39\% gospodarstw w ogóle nie stosuje nawozów mineralnych (GUS, 2017), co oznacza, że rzeczywiste dawki $\mathrm{N}$ na gruntach ornych moga być większe niż wynikałoby to z danych GUS. W UE27 średnia dawka stosowanego N wynosi $110 \mathrm{~kg} \mathrm{ha}^{-1}$, a krytyczne dawki tego składnika wynoszą; ze względu na ochronę wód dawka $92 \mathrm{~kg} \mathrm{ha}^{-1}$, natomiast ze względu na ochronę atmosfery $88 \mathrm{~kg} \mathrm{ha}^{-1}$ (de Vries i Kros, 2016). Dawki stosowane w badaniach własnych były więc większe od dawek krytycznych z punktu widzenia ochrony środowiska.

Tabela 1. Dawki zastosowanego azotu w nawozach naturalnych i mineralnych $\left(\mathrm{kg} \mathrm{N}^{-1} \mathrm{r}^{-1}\right)$

Table 1. Doses of nitrogen used in natural and mineral fertilizers $\left(\mathrm{kg} \mathrm{N} \mathrm{ha}^{-1} \mathrm{r}^{-1}\right)$

\begin{tabular}{|c|c|c|c|c|}
\hline \multirow{2}{*}{ Województwo } & \multicolumn{3}{|c|}{ Systemy uprawy } & \multirow{2}{*}{ Średnia ważona } \\
\hline & $\mathrm{a}$ & $\mathrm{b}$ & $\mathrm{c}$ & \\
\hline Dolnośląskie & 97 & 145 & 108 & 122 \\
\hline Kujawsko-pomorskie & 97 & 152 & 144 & 142 \\
\hline Lubelskie & 89 & 152 & 129 & 134 \\
\hline Lubuskie & 102 & 165 & 130 & 141 \\
\hline Łódzkie & 102 & 163 & 136 & 143 \\
\hline Małopolskie & 88 & 140 & 119 & 124 \\
\hline Mazowieckie & 98 & 160 & 132 & 140 \\
\hline Opolskie & 83 & 139 & 123 & 125 \\
\hline Podkarpackie & 63 & 144 & 124 & 126 \\
\hline Podlaskie & 97 & 148 & 128 & 133 \\
\hline Pomorskie & 96 & 151 & 127 & 134 \\
\hline Śląskie & 91 & 156 & 124 & 133 \\
\hline Świętokrzyskie & 96 & 147 & 129 & 133 \\
\hline Warmińsko-mazurskie & 99 & 156 & 129 & 137 \\
\hline Wielkopolskie & 103 & 149 & 139 & 140 \\
\hline Zachodniopomorskie & 98 & 154 & 131 & 137 \\
\hline Polska & 96 & 153 & 130 & 136 \\
\hline
\end{tabular}

Źródło: opracowanie własne. 


\section{A. Faber, Z. Jarosz}

Pożądane pobranie $\mathrm{N}$ przez rośliny powinno wynosić, jak się uważa, co najmniej 80 $\mathrm{kg} \mathrm{N} \mathrm{ha}{ }^{-1}$ (EU Nitrogen Expert Panel, 2015). Tam, gdzie we wszystkich badanych systemach uprawy było ono mniejsze niż $80 \mathrm{~kg} \mathrm{~N} \mathrm{ha}^{-1}$ decydowały o tym małe pobrania $\mathrm{N}$ na glebach bardzo lekkich (tab. 2). Pozostawienie na polu resztek pożniwnych w wielu województwach powodowało obniżenie pobierania N (tab. 2), co oznacza, że mimo dodatkowego nawożenia $\mathrm{N}$ dostępność tego składnika dla roślin była obniżana wskutek rozkładu słomy. Nawożenie obornikiem z reguły nieznacznie zwiększało pobranie $\mathrm{N} \mathrm{w}$ stosunku do systemów uprawy (a) i (b). W skali kraju pobrania $\mathrm{N}$ były większe od pożądanego i wahały się w granicach $93-101 \mathrm{~kg} \mathrm{ha}^{-1}$ (tab. 2).

Tabela 2. Pobranie azotu wraz z plonem głównym i ubocznym $\left(\mathrm{kg} \mathrm{N} \mathrm{ha}^{-1} \mathrm{r}^{-1}\right)$

Table 2. Nitrogen uptake along with main and side yield $\left(\mathrm{kg} \mathrm{N} \mathrm{ha}^{-1} \mathrm{r}^{-1}\right)$

\begin{tabular}{|c|c|c|c|c|}
\hline \multirow{2}{*}{ Województwo } & \multicolumn{3}{|c|}{ System uprawy } & \multirow{2}{*}{ Średnia ważona } \\
\hline & $\mathrm{a}$ & $\mathrm{b}$ & $\mathrm{c}$ & \\
\hline Dolnośląskie & 66 & 61 & 69 & 65 \\
\hline Kujawsko-pomorskie & 96 & 73 & 99 & 88 \\
\hline Lubelskie & 72 & 65 & 83 & 74 \\
\hline Lubuskie & 110 & 101 & 112 & 108 \\
\hline Łódzkie & 108 & 108 & 116 & 112 \\
\hline Małopolskie & 52 & 49 & 63 & 57 \\
\hline Mazowieckie & 106 & 106 & 111 & 108 \\
\hline Opolskie & 69 & 62 & 76 & 70 \\
\hline Podkarpackie & 75 & 71 & 98 & 85 \\
\hline Podlaskie & 100 & 104 & 108 & 106 \\
\hline Pomorskie & 101 & 73 & 104 & 91 \\
\hline Śląskie & 58 & 81 & 92 & 84 \\
\hline Świętokrzyskie & 95 & 95 & 104 & 100 \\
\hline Warmińsko-mazurskie & 96 & 98 & 100 & 98 \\
\hline Wielkopolskie & 113 & 107 & 120 & 114 \\
\hline Zachodniopomorskie & 80 & 113 & 107 & 107 \\
\hline Polska & 96 & 93 & 101 & 98 \\
\hline
\end{tabular}

Źródło: opracowanie własne.

Azot nie pobrany przez rośliny w $80-100 \%$ podlega stratom poprzez wymycie i emisje gazowe (Billen i in., 2014). Na wielkości wymycia $\mathrm{N}$ znaczący wpływ miały wymycia $\mathrm{z}$ gleb bardzo lekkich (dane nie prezentowane). W systemach uprawy (b) i (c), w których podaż węgla organicznego była zwiększona i większe było nawożenie $\mathrm{N}$ wymycie azotu znacząco rosło. W skali kraju ten wzrost był około 2-krotny (tab. 3). Średnie wymycie i spływ powierzchniowy $\mathrm{N}$ w UE27 szacowany jest na 13,9 $\mathrm{kg} \mathrm{ha}^{-1}$, zaś krytyczne dla zanieczyszczenia wód wymycie wynosi $5,8 \mathrm{~kg} \mathrm{ha}^{-1}$, natomiast krytyczna ilość wymycia $\mathrm{N}$ dla zanieczyszczenia atmosfery wynosi $10,3 \mathrm{~kg} \mathrm{ha}^{-1}$ (de Vries i Kros, 2016). Stwierdzone w badaniach własnych wymycia w systemach uprawy (b) i (c) były znacznie większe od wielkości krytycznych. Oznacza to, że badane systemy mogą potencjalnie zwiększać ryzyko strat $\mathrm{N}$ na obszarach ochrony wód przed zanieczyszczeniem azotem. 
Tabela 3. Wymycie azotu $\mathrm{z}$ nawożonych gleb $\left(\mathrm{kg} \mathrm{N} \mathrm{ha}^{-1} \mathrm{r}^{-1}\right)$

Table 3. Leaching of nitrogen from fertilized soils $\left(\mathrm{kg} \mathrm{N} \mathrm{ha}^{-1} \mathrm{r}^{-1}\right)$

\begin{tabular}{l|cccc}
\hline \multirow{2}{*}{ Województwo } & \multicolumn{3}{c}{ System uprawy } & Średnia ważona \\
\cline { 2 - 4 } & $\mathrm{a}$ & $\mathrm{b}$ & 63 & 61 \\
\hline Dolnośląskie & 32 & 66 & 37 & 33 \\
Kujawsko-pomorskie & 15 & 32 & 56 & 53 \\
Lubelskie & 27 & 57 & 19 & 20 \\
Lubuskie & 10 & 23 & 15 & 16 \\
Lódzkie & 8 & 19 & 53 & 47 \\
Małopolskie & 32 & 45 & 16 & 15 \\
Mazowieckie & 7 & 14 & 48 & 47 \\
Opolskie & 24 & 51 & 49 & 48 \\
Podkarpackie & 25 & 52 & 20 & 21 \\
Podlaskie & 15 & 24 & 30 & 27 \\
Pomorskie & 16 & 27 & 25 & 32 \\
Śląskie & 20 & 44 & 20 & 20 \\
Świętokrzyskie & 17 & 20 & 27 & 27 \\
Warmińsko-mazurskie & 17 & 31 & 15 & 14 \\
Wielkopolskie & 7 & 15 & 20 & 25 \\
Zachodniopomorskie & 11 & 34 & 28 & 28 \\
Polska & 15 & 31 & & \\
\hline
\end{tabular}

Źródło: opracowanie własne.

Tabela 4. Spływ powierzchniowy azotu $\left(\mathrm{kg} \mathrm{N} \mathrm{ha}^{-1} \mathrm{r}^{-1}\right)$

Table 4. Surface runoff of nitrogen $\left(\mathrm{kg} \mathrm{N} \mathrm{ha}^{-1} \mathrm{r}^{-1}\right)$

\begin{tabular}{|c|c|c|c|c|}
\hline \multirow{2}{*}{ Województwo } & \multicolumn{3}{|c|}{ System uprawy } & \multirow{2}{*}{ Średnia ważona } \\
\hline & $\mathrm{a}$ & $\mathrm{b}$ & $\mathrm{c}$ & \\
\hline Dolnośląskie & 0,90 & 2,46 & 3,14 & 2,64 \\
\hline Kujawsko-pomorskie & 0,67 & 1,42 & 1,72 & 1,49 \\
\hline Lubelskie & 0,78 & 2,01 & 2,58 & 2,17 \\
\hline Lubuskie & 0,42 & 1,48 & 1,25 & 1,26 \\
\hline Łódzkie & 0,31 & 0,87 & 1,12 & 0,94 \\
\hline Małopolskie & 0,32 & 1,68 & 2,37 & 1,89 \\
\hline Mazowieckie & 0,24 & 0,88 & 0,94 & 0,85 \\
\hline Opolskie & 0,65 & 1,66 & 2,24 & 1,85 \\
\hline Podkarpackie & 0,28 & 0,88 & 1,30 & 1,03 \\
\hline Podlaskie & 1,15 & 2,45 & 1,62 & 1,91 \\
\hline Pomorskie & 0,43 & 1,03 & 2,66 & 1,78 \\
\hline Śląskie & 0,55 & 1,44 & 0,94 & 1,10 \\
\hline Świętokrzyskie & 0,42 & 1,07 & 1,03 & 0,99 \\
\hline Warmińsko-mazurskie & 0,78 & 1,54 & 1,55 & 1,47 \\
\hline Wielkopolskie & 0,34 & 1,35 & 1,26 & 1,20 \\
\hline Zachodniopomorskie & 0,50 & 2,60 & 1,20 & 1,69 \\
\hline Polska & 0,46 & 1,25 & 1,50 & 1,30 \\
\hline
\end{tabular}

Źródło: opracowanie własne. 
Spływ powierzchniowy N w systemach uprawy (b) i (c) wzrastał 2-3-krotnie w porównaniu z systemem uprawy (a) (tab. 4). Sumując wymycie i spływ powierzchniowy $\mathrm{N}$ otrzymano straty azotu do wód wynoszące dla (a), (b) i (c) odpowiednio: 15,5; 32,2 oraz $29,5 \mathrm{~kg} \mathrm{~N} \mathrm{ha}^{-1}$. Stanowiły one odpowiednio: 16, 21 i 23\% zastosowanego N w nawozach. Straty te były mniejsze od domyślnego współczynnika, którego wartość wynosi 30\% (IPCC, 2006c). Wartości uzyskane są bliższe wskaźnikowi stosowanemu w Norwegii, który ustalono na 22\% stosowanej dawki N (Bechmann i in., 2012).

Emisje bezpośrednie $\mathrm{N}_{2} \mathrm{O}$ były najmniejsze w systemie uprawy (a) i rosły wielokrotnie w systemach (b) i (c) (tab. 5). W skali kraju wzrosty emisji tego gazu w systemach sekwestrujących węgiel, w stosunku do (a), były odpowiednio 4,0 i 2,6-krotne. Oszacowane emisje mieściły się w przedziałach od $<1$ do $3 \mathrm{~kg} \mathrm{~N}_{2} \mathrm{O}-\mathrm{N} \mathrm{ha}^{-1} \mathrm{r}^{-1}$ uzyskanych według innych symulacji (Lesschen i in., 2011).

Tabela 5. Emisja bezpośrednia podtlenku azotu $\left(\mathrm{kg} \mathrm{N}_{2} \mathrm{O}-\mathrm{N} \mathrm{ha}^{-1} \mathrm{r}^{-1}\right)$

Table 5. Direct emission of nitrous oxide $\left(\mathrm{kg} \mathrm{N}_{2} \mathrm{O}-\mathrm{N} \mathrm{ha}^{-1} \mathrm{r}^{-1}\right)$

\begin{tabular}{|c|c|c|c|c|}
\hline \multirow{2}{*}{ Województwo } & \multicolumn{3}{|c|}{ System uprawy } & \multirow{2}{*}{ Średnia ważona } \\
\hline & $\mathrm{a}$ & $\mathrm{b}$ & $\mathrm{c}$ & \\
\hline Dolnośląskie & 0,94 & 3,19 & 2,66 & 2,70 \\
\hline Kujawsko-pomorskie & 0,43 & 1,80 & 1,76 & 1,64 \\
\hline Lubelskie & 0,56 & 2,58 & 2,06 & 2,12 \\
\hline Lubuskie & 0,39 & 1,89 & 1,14 & 1,37 \\
\hline Łódzkie & 0,35 & 1,63 & 0,88 & 1,13 \\
\hline Małopolskie & 0,61 & 2,25 & 1,80 & 1,86 \\
\hline Mazowieckie & 0,24 & 1,10 & 0,80 & 0,86 \\
\hline Opolskie & 0,54 & 2,29 & 1,68 & 1,81 \\
\hline Podkarpackie & 0,43 & 1,69 & 1,34 & 1,39 \\
\hline Podlaskie & 0,77 & 2,13 & 1,25 & 1,55 \\
\hline Pomorskie & 0,35 & 1,29 & 0,95 & 1,02 \\
\hline Śląskie & 0,61 & 2,02 & 1,05 & 1,39 \\
\hline Świętokrzyskie & 0,48 & 1,44 & 1,11 & 1,18 \\
\hline Warmińsko-mazurskie & 0,49 & 1,55 & 1,03 & 1,19 \\
\hline Wielkopolskie & 0,35 & 1,54 & 1,19 & 1,25 \\
\hline Zachodniopomorskie & 0,39 & 2,17 & 1,00 & 1,40 \\
\hline Polska & 0,46 & 1,85 & 1,22 & 1,40 \\
\hline
\end{tabular}

Źródło: opracowanie własne.

Emisje $\mathrm{N}_{2} \mathrm{O}$ wyrażone w \% dawki pozwalają odnieść uzyskane wyniki do domyślnego współczynnika emisji, który według IPCC (2006c) wynosi $1 \%$ zastosowanej dawki N w nawozach (tab. 6). W systemie (a) emisje były mniejsze niż 1\% i rosły w systemach (b) i (c). W Polsce jednak średni ważony współczynnik emisji dla trzech badanych systemów uprawy był bliski wartości podanej przez IPCC i wynosił 1,03\% zastosowanej dawki N. 
Tabela 6. Emisja bezpośrednia podtlenku azotu w stosunku do dawki (\%)

Table 6. Direct emission of nitrous oxide in relation to the dose (\%)

\begin{tabular}{l|cccc}
\hline \multirow{2}{*}{ Województwo } & \multicolumn{3}{c}{ System uprawy } & \multirow{2}{*}{ Srednia ważona } \\
\cline { 2 - 4 } Dolnośląskie & $\mathrm{a}$ & $\mathrm{b}$ & $\mathrm{c}$ & 2,78 \\
Kujawsko-pomorskie & 0,96 & 3,29 & 1,74 & 1,13 \\
Lubelskie & 0,44 & 1,18 & 1,60 & 1,55 \\
Lubuskie & 0,63 & 1,70 & 0,88 & 0,94 \\
Lódzkie & 0,38 & 1,15 & 0,64 & 1,47 \\
Małopolskie & 0,35 & 1,00 & 1,51 & 0,60 \\
Mazowieckie & 0,69 & 1,61 & 0,61 & 1,41 \\
Opolskie & 0,25 & 0,68 & 1,37 & 1,08 \\
Podkarpackie & 0,65 & 1,65 & 1,08 & 1,14 \\
Podlaskie & 0,69 & 1,17 & 0,98 & 0,75 \\
Pomorskie & 0,79 & 1,44 & 0,75 & 1,01 \\
Śląskie & 0,36 & 0,85 & 0,84 & 0,87 \\
Świętokrzyskie & 0,68 & 1,30 & 0,87 & 0,85 \\
Warmińsko-mazurskie & 0,50 & 0,98 & 0,80 & 0,87 \\
Wielkopolskie & 0,49 & 1,00 & 0,86 & 0,98 \\
Zachodniopomorskie & 0,34 & 1,03 & 0,76 & 1,03 \\
Polska & 0,39 & 1,41 & 0,94 & \\
\hline
\end{tabular}

Źródło: opracowanie własne.

Tabela 7. Emisja amoniaku $\left(\mathrm{kg} \mathrm{NH}_{3}-\mathrm{N} \mathrm{ha}^{-1} \mathrm{r}^{-1}\right)$

Table 7. Ammonia emission ( $\left.\mathrm{kg} \mathrm{NH}_{3}-\mathrm{N} \mathrm{ha}^{-1} \mathrm{r}^{-1}\right)$

\begin{tabular}{l|cccc}
\hline \multirow{2}{*}{ Województwo } & \multicolumn{3}{c}{} & Śs.ednia ważona \\
\cline { 2 - 4 } Dolnośląskie & $\mathrm{a}$ & $\mathrm{b}$ & 3,37 & 2,24 \\
Kujawsko-pomorskie & 0,88 & 1,16 & 3,97 \\
Lubelskie & 2,66 & 3,23 & 4,83 & 2,61 \\
Lubuskie & 1,39 & 1,57 & 3,70 & 3,93 \\
Lódzkie & 3,08 & 3,20 & 4,69 & 4,18 \\
Małopolskie & 3,40 & 3,28 & 2,40 \\
Mazowieckie & 1,23 & 1,30 & 3,05 & 3,88 \\
Opolskie & 3,20 & 3,24 & 4,52 & 2,87 \\
Podkarpackie & 1,51 & 2,04 & 3,81 & 2,97 \\
Podlaskie & 1,66 & 1,69 & 4,26 & 4,02 \\
Pomorskie & 2,80 & 3,85 & 4,39 & 3,64 \\
Śląskie & 2,78 & 2,88 & 4,42 & 3,02 \\
Świętokrzyskie & 2,28 & 2,57 & 3,53 & 3,23 \\
Warmińsko-mazurskie & 2,45 & 2,23 & 4,18 & 2,89 \\
Wielkopolskie & 2,34 & 2,17 & 3,58 & 3,81 \\
Zachodniopomorskie & 2,96 & 3,30 & 4,39 & 3,14 \\
Polska & 2,66 & 2,25 & 3,94 & 3,40 \\
\hline
\end{tabular}

Źródło: opracowanie własne. 


\section{A. Faber, Z. Jarosz}

Amoniak nie jest gazem cieplarnianym, jednakże 1\% jego ilości, wyrażonej w $\mathrm{N}$, ulega przekształceniu w $\mathrm{N}_{2} \mathrm{O}$ (IPCC, 2006c). Stwierdzone w eksperymencie symulacyjnym emisje $\mathrm{NH}_{3}$ można pod względem wielkości przedstawić jako szereg rosnący (a) $<$ (b) $<$ (c) (tab. 8). Nawożenie obornikiem w sposób znaczący zwiększało emisje amoniaku w Polsce. Według innych danych całkowite emisje $\mathrm{NH}_{3}-\mathrm{N}$ na przeważającym obszarze Polski mieszczą się w granicach $1-10 \mathrm{~kg} \mathrm{ha}^{-1} \mathrm{r}^{-1}$ (Bieńkowski J., 2010; Leip i in., 2011).

Tabela 8. Emisja amoniaku w stosunku do dawki (\%)

Table 8. Ammonia emission in relation to the dose $(\%)$

\begin{tabular}{|c|c|c|c|c|}
\hline \multirow{2}{*}{ Województwo } & \multicolumn{3}{|c|}{ System uprawy } & \multirow{2}{*}{ Średnia ważona } \\
\hline & $\mathrm{a}$ & $\mathrm{b}$ & $\mathrm{c}$ & \\
\hline Dolnośląskie & 0,90 & 0,80 & 3,11 & 1,97 \\
\hline Kujawsko-pomorskie & 2,74 & 2,12 & 3,36 & 2,80 \\
\hline Lubelskie & 1,57 & 1,03 & 2,88 & 2,01 \\
\hline Lubuskie & 3,01 & 1,94 & 3,60 & 2,88 \\
\hline Łódzkie & 3,35 & 2,01 & 3,71 & 3,00 \\
\hline Małopolskie & 1,39 & 0,93 & 2,95 & 1,98 \\
\hline Mazowieckie & 3,28 & 2,02 & 3,45 & 2,86 \\
\hline Opolskie & 1,82 & 1,47 & 3,09 & 2,32 \\
\hline Podkarpackie & 2,64 & 1,17 & 3,44 & 2,45 \\
\hline Podlaskie & 2,88 & 2,60 & 3,43 & 3,05 \\
\hline Pomorskie & 2,91 & 1,91 & 3,47 & 2,79 \\
\hline Śląskie & 2,52 & 1,65 & 2,85 & 2,34 \\
\hline Świętokrzyskie & 2,56 & 1,52 & 3,25 & 2,49 \\
\hline Warmińsko-mazurskie & 2,35 & 1,39 & 2,78 & 2,18 \\
\hline Wielkopolskie & 2,88 & 2,21 & 3,15 & 2,75 \\
\hline Zachodniopomorskie & 2,71 & 1,46 & 3,01 & 2,36 \\
\hline Polska & 2,63 & 1,71 & 3,24 & 2,50 \\
\hline \multicolumn{5}{|c|}{ Źródło: opracowanie własne. } \\
\hline \multicolumn{5}{|c|}{$\begin{array}{l}\text { Tabela 9. Emisja pośrednia podtlenku azotu }\left(\mathrm{kg} \mathrm{N}_{2} \mathrm{O}-\mathrm{N} \mathrm{ha}^{-1} \mathrm{r}^{-1}\right) \\
\text { Table 9. Indirect emission of nitrous oxide }\left(\mathrm{kg} \mathrm{N}_{2} \mathrm{O}-\mathrm{N} \mathrm{ha}^{-1} \mathrm{r}^{-1}\right)\end{array}$} \\
\hline \multirow{2}{*}{ Województwo } & \multicolumn{3}{|c|}{ System uprawy } & \multirow{2}{*}{ Średnia ważona } \\
\hline & $\mathrm{a}$ & $\mathrm{b}$ & $\mathrm{c}$ & \\
\hline Dolnośląskie & 0,26 & 0,52 & 0,53 & 0,50 \\
\hline Kujawsko-pomorskie & 0,14 & 0,28 & 0,34 & 0,29 \\
\hline Lubelskie & 0,22 & 0,46 & 0,47 & 0,44 \\
\hline Lubuskie & 0,11 & 0,21 & 0,20 & 0,20 \\
\hline Łódzkie & 0,10 & 0,18 & 0,17 & 0,17 \\
\hline Małopolskie & 0,21 & 0,48 & 0,49 & 0,46 \\
\hline Mazowieckie & 0,09 & 0,15 & 0,17 & 0,16 \\
\hline Opolskie & 0,20 & 0,41 & 0,42 & 0,39 \\
\hline Podkarpackie & 0,19 & 0,39 & 0,38 & 0,37 \\
\hline Podlaskie & 0,15 & 0,24 & 0,21 & 0,21 \\
\hline Pomorskie & 0,15 & 0,24 & 0,29 & 0,25 \\
\hline Śląskie & 0,18 & 0,37 & 0,23 & 0,28 \\
\hline Świętokrzyskie & 0,15 & 0,25 & 0,24 & 0,24 \\
\hline Warmińsko-mazurskie & 0,13 & 0,25 & 0,22 & 0,22 \\
\hline Wielkopolskie & 0,09 & 0,15 & 0,17 & 0,15 \\
\hline Zachodniopomorskie & 0,11 & 0,30 & 0,20 & 0,23 \\
\hline Polska & 0,14 & 0,26 & 0,26 & 0,25 \\
\hline
\end{tabular}

Źródło: opracowanie własne. 
Emisje $\mathrm{NH}_{3}$ w procentach dawki (tab. 8) były w systemie (a) większe od współczynnika emisji dla saletry amonowej, który wynosi 1,6\% zastosowanej dawki $\mathrm{N}$ (EMEP/EEA, 2016). Pozostawienie na polu resztek pożniwnych generalnie w niewielkim stopniu wpływało na emisję $\mathrm{NH}_{3}$, a nawożenie obornikiem zwiększało jego emisję (tab. 8).

Emisje pośrednie $\mathrm{N}_{2} \mathrm{O}$ szacuje się stosując współczynnik emisji $1 \%$ dla $\mathrm{NH}_{3}-\mathrm{N}$ oraz $0,75 \%$ dla wymywanego $\mathrm{N}$ (wymycie i spływ powierzchniowy). Można je przedstawić jako szereg rosnący dla systemów uprawy: $(a)<(b)=(c)($ tab. 9). W kraju wahały się one w granicach $0,14-0,26 \mathrm{~kg} \mathrm{~N}_{2} \mathrm{O}-\mathrm{N} \mathrm{ha}^{-1}$, co stanowiło 14-30\% emisji bezpośredniej tego gazu.

Tabela 10. Medianowe odchylenia bezwzględne (MAD) w stosunku do median zmiennych charakteryzujących gospodarkę azotem w systemach uprawy w Polsce (\%)

Table 10. Median absolute deviations (MAD) in relation to median of variables characterizing the nitrogen economy in cultivation systems in Poland (\%)

\begin{tabular}{l|ccc}
\hline \multirow{2}{*}{ Zmienna } & \multicolumn{3}{c}{ Uprawa } \\
\cline { 2 - 4 } & $\mathrm{a}$ & $\mathrm{b}$ & $\mathrm{c}$ \\
\hline Emisja $\mathrm{N}_{2} \mathrm{O}$ & 76 & 69 & 69 \\
Emisja $\mathrm{NH}_{3}$ & 74 & 54 & 80 \\
\hline
\end{tabular}

Źródło: opracowanie własne.

Miarą zmienności przedstawionych oszacowań dla emisji $\mathrm{N}_{2} \mathrm{O}$ i $\mathrm{NH}_{3}$ dla Polski moga być medianowe odchylenia bezwzględne (tab. 10). Wahają się one w granicach $54-80 \%$. Niepewność współczynnika emisji według IPCC (2006c) wynosi dla $\mathrm{N}_{2} \mathrm{O}$ 0,3-3,0\% (wartość domyślna 1\%), co odpowiada zmienności $\mathrm{N}_{2} \mathrm{O}$ od -30 do 300\%. Na wielkości emisji $\mathrm{N}_{2} \mathrm{O}$ oraz niepewności ich pomiarów i szacunków mogą mieć wpływ czynniki środowiskowe (klimat, właściwości gleb) oraz stosowane praktyki rolnicze (dawki N, rodzaje nawozów, gatunki roślin) (Bouwman i in., 2002). Niepewność współczynnika dla amoniaku wynosi $\pm 50 \%$ (EMEP/EEA, 2016). Porównanie podanych wartości wskazuje, że zmienności symulowanych wartości badanych zmiennych leżą dla $\mathrm{N}_{2} \mathrm{O}$ bliżej minimalnych przedziałów wartości IPCC, zaś dla $\mathrm{NH}_{3}$ są nieco większe niż niepewności według EMEP/EEA (2016).

\section{Podsumowanie}

Przedmiotem badań była weryfikacja przyjętych w krajowych inwentaryzacjach emisji gazów cieplarnianych współczynników emisji bezpośredniej $\mathrm{N}_{2} \mathrm{O}$ i $\mathrm{NH}_{3}$ oraz oszacowanie emisji bezpośredniej i pośredniej $\mathrm{N}_{2} \mathrm{O}$ w systemach uprawy sprzyjających sekwestracji węgla.

Stwierdzono, że średnia ważona symulowana emisja bezpośrednia $\mathrm{N}_{2} \mathrm{O}$ dla Polski wynosiła 1,03\% zastosowanej dawki $\mathrm{N}$ i była bardzo bliska współczynnikowi emisji zalecanemu przez IPCC (1\%). Symulowana emisja amoniaku dla Polski wynosiła 2,5\% zastosowanej dawki N w saletrze amonowej i była 1,5-krotnie większa od współczynnika emisji dla saletry amonowej według EMEP/EEA (1,6\%). Zastosowanie modelowania (metoda poziomu 3) nie prowadziło do obniżenia szacunków emisji, choć zmienność szacunków emisji była umiarkowana. 
Zastosowanie w symulacjach systemów uprawy zwiększających sekwestrację węgla organicznego, takich jak uprawa konserwująca oraz nawożenie obornikiem, zwiększało wymycie i spływ powierzchniowy $\mathrm{N}$ oraz emisję bezpośrednią i pośrednią $\mathrm{N}_{2} \mathrm{O}$. Wzrost tych emisji powinien być kompensowany z naddatkiem przyrostem ilości sekwestrowanego węgla organicznego w glebie, jeśli bilans emisji gazów cieplarnianych ma być ujemny.

\section{Literatura}

Bechmann, M., Greipsland, I., Riley, H., Eggestad, H.O. (2012). Nitrogen losses from agricultural areas. A fraction of applied fertilizer and manure (FracLEACH). Bioforsk. Pobrane 29 marca 2018 z: http://www.bioforsk.no/ ikbViewer/Content/99316/Rapport120901FracLEACH.pdf.

Bieńkowski, J. (2010). Regionalne zróżnicowanie emisji amoniaku w polskim rolnictwie w latach 2005-2007 (Regional differentiation of ammonia emission in Polish agriculture in the years 2005-2007). Fragmenta Agronomica 27(1), 21-31.

Billen, G., Lassaletta, L., Garnier, J. (2014). Some conceptual and methodological aspects of NUE of agro-food systems. The note at the attention of the EU N-expert panel. Winsor, Sept. 15-16, 2014 (manuscript).

Bouwmann, A.F., Boumans, L.J.M., Batjes, N.H. (2002). Modeling global annual $\mathrm{N}_{2} \mathrm{O}$ and NO emissions from fertilized fields. Global Biogeochemical Cycles, 16 (4), 1080.

DNDC. Global DNDC Network. Pobrane 29 marca 2018 z: http://www.globaldndc.net/information/publications-i3.html.

Dziennik Ustaw (2005). Protokół z Kioto do ramowej konwencji Narodów Zjednoczonych w sprawie zmian klimatu (Kyoto Protocol to the United Nations Framework Convention on Climate Change). $\begin{array}{lllll}\text { Dz.U.05.203.1684. } & \text { Pobrane } & 29 & \text { marca } & \end{array}$ https://www.mos.gov.pl/fileadmin/user_upload/srodowisko/Protokol_z_Kioto_ do_Ramowej_Konwencji_Narodow_Zjednoczonych_w_sprawie_zmiān_klimātu.pdf.

Dziennik Urzędowy Unii Europejskiej (2016). Umowy Międzynarodowe. DECYZJA RADY (UE) 2016/1841 z dnia 5 października 2016 r. w sprawie zawarcia, w imieniu Unii Europejskiej, porozumienia paryskiego przyjętego na mocy Ramowej konwencji Narodów Zjednoczonych w sprawie zmian klimatu (COUNCIL DECISION (EU) 2016/1841 of 5 October 2016 on the conclusion, on behalf of the European Union, of the Paris Agreement adopted under the United Nations Frame work Convention on Climate Change). 19.10.2016, L 282/1. Pobrane $29 \quad$ marca $2018 \quad \mathrm{z}$ : https://eurlex.europa.eu/legalcontent/PL/TXT/PDF/?uri=CELEX:32016D 1841\& from=PL.

EMEP/EEA: EMEP/EEA air pollutant emission inventory guidebook (2016). European Environment Agency, Copenhagen.

European Commission (2016a). Proposal for an Effort Sharing Regulation 2021-2030. Pobrane 29 marca 2018 z: https://ec.europa.eu/clima/policies/effort/proposal_en.

European Commission (2016b). Land use and forestry proposal for 2021-2030. Pobrane 29 marca $2018 \mathrm{z}$ : https://ec.europa.eu/clima/lulucf_en.

EU Nitrogen Expert Panel (2015). Nitrogen Use Efficiency (NUE) - an indicator for the utilization of nitrogen in agriculture and food systems. Wageningen University, Alterra, PO Box 47, NL-6700 Wageningen, Netherlands.

Giltrap, D.L., Li, C., Saggar, S. (2010). DNDC: A process-based model of greenhouse gas fluxes from agricultural soil. Agriculture, Ecosystems and Environment, 136, 292-300.

GUS (2018a). Środki produkcji w rolnictwie w roku 2016/2017 (Means of production in agriculture in the 2016/2017 farming year). Warszawa.

GUS (2018b). Użytkowanie gruntów i powierzchnia zasiewów w 2017 roku (Land use and sown area in 2017). Warszawa.

GUS (2017). Charakterystyka gospodarstw rolnych w 2016 (Characteristics of agricultural holdings in 2016). Warszawa.

IPCC (2013). Zmiana klimatu 2013. Fizyczne podstawy naukowe. Podsumowanie dla decydentów (Climate Change 2013. The Physical Science Basis. Summary for decision-makers). WMO, UNEP. Pobrane 29 marca 2018 z: https://www.ipcc.ch/pdf/reports-nonUN-translations/polish/ar5-wg1-spm.pdf.

IPCC (2006a). 2006 IPCC Guidelines for National Greenhouse Gas Inventories. Chapter 5: Cropland. Pobrane 29 marca 2018 z: https://www.ipcc_nggip.iges.or.jp/public/2006gl/pdf/4_Volume4/V4_05_Ch5_Cropland.pdf. 
IPCC (2006b). 2006 IPCC Guidelines for National Greenhouse Gas Inventories. Chapter 2: Generic Methodologies Applicable to Multiple Land-Use Categories. Pobrane 29 marca 2018 z: https://www.ipccnggip.iges.or.jp/public/2006gl/pdf/4 Volume4/V4 02 Ch2 Generic.pdf.

IPCC (2006c) 2006 IPCC Guidelines for National Greenhouse Gas Inventories. Chapter 11: N2O Emissions from Managed Soils, and CO2 Emissions from Lime and Urea Application. Pobrane 29 marca 2018 z: https://www.ipcc-nggip.iges.or.jp/public/2006gl/pdf/4_Volume4/V4_11_Ch11_N2O\&CO2.pdf.

Jadczyszyn, T., Kowalczyk, J., Sroczyński, W. (2003). Zalecenia nawozowe dla gospodarstw korzystających z wyników badań zasobności gleb (Recommendations fertilizer for farms benefiting from the results of surveys of the soil). PWRiL.

Leip, A., Marchi, G., Koeble, R., Kempen, M., Britz, W., Li, C. (2007). Linking an economic model for European agriculture with a mechanistic model to estimate nitrogen losses from cropland soil in Europe. Biogeosciences Discussions, 4, 2215-2278.

Leip, A., Marchi, G., Koeble, R., Kempen, M., Britz, W., Li, C. (2008). Linking an economic model for European agriculture with a mechanistic model to estimate nitrogen and carbon losses from arable soils in Europe. Biogeoscience, 5, 73-94.

Leip, A., Achermann, B., Billen, G., Bleeker, A., Bouwman, A.F., de Vries, W., Dragosits, U., Döring, U., Fernall, D., Geupel, M., Heldstab, J., Johnes, P., Le Gall, A.C., Monni, S., Nevečeřal, R., Orlandini, L., Prud'homme, M., Reuter, H.I., Simpson, D., Seufert, G., Spranger, T., Sutton, M.A., van Aardenne, J., Voß, M., Winiwarter, W. (2011). Integrating nitrogen fluxes at the European scale. Chapter 16. W: Sutton et al The European Nitrogen Assessment. Sources, Effects and Policy Perspectives. Cambridge University Press, 345-376.

Lesschen, J.P., Velthof, G.L., de Vries, W., Kros, J. (2011). Differentiation of nitrous oxide emission factors for agricultural soils. Environmental Pollution, 159, 3215-3222.

UNFCCC, (1992). Ramowa Konwencja Narodów Zjednoczonych w sprawie zmian klimatu. Pobrane 29 marca $2018 \mathrm{z}$ : https://www.mos.gov.pl/fileadmin/user_upload/srodowisko/Ramowa_Konwencja_Narodow_ Zjednoczonych w sprawie zmian klimatu.pdf.

United Nation Climate Change. Lānd Use, Land-Use Change and Forestry (LULUCF). (2018). Pobrane 29 marca $2018 \mathrm{z}$ : http://unfccc.int/land_use_and_climate_change/lulucf/items/1084.php.

de Vries, W., Kros, J. (2016). Proceedings of the 2016. Assessment of current and critical nitrogen inputs on European agricultural Soils. International Nitrogen Initiative Conference, "Solutions to improve nitrogen use efficiency for the world", 4 - 8 December 2016, Melbourne, Australia.

Do cytowania / For citation:

Faber A., Jarosz Z. (2018). Modelowanie emisji podtlenku azotu i amoniaku w skali regionalnej oraz w Polsce. Problemy Rolnictwa Światowego, 18(2), 70-81; DOI: 10.22630/PRS.2018.18.2.35

Faber A., Jarosz Z. (2018). Modeling of Emission of Nitrous Oxide and Ammonia on a Regional Scale and in Poland (in Polish). Problems of World Agriculture, 18(2), 70-81;

DOI: 10.22630/PRS.2018.18.2.35 